\title{
"Digging deeper" evidence on water crisis and its solution in Nigeria for Bayelsa state: a study of current scenario
}

\begin{abstract}
By 2023, global population is expected to reach 8 billion and increasing demand on freshwater resources over the next decades including continuation of economic development will increase pressure on the earth's finite resources. As a result, bold and novel solutions is required for today's human development despite it challenges. Since, the adoption of the United Nations Sustainable Development Goals (SDGs) in 2015 marked a new level of political recognition of the importance of water to development. For the first time, this included a target to ensure access to affordable, reliable and sustainable water for all - collectively known as Sustainable Development Goal 5. Interestingly, the fundamental starting point for food and life is water and its scarcity are a critical global issue. Over the past century, the quest for development has spurred the desire to explore the possibilities of harnessing all resources to advantage including water, which is $75 \%$ human made water content, while the whole earth is $70 \%$ water. These efforts were such that cogniscance has not been given to the environment where the entire processes take place. Consequently, around the world 2.2 billion people lack access to adequate supplies of water and close to 4.2 billion people suffer from the consequences of poor sanitation. Millions of people, especially children, die each year from contaminated water and about $95 \%$ of deadly diseases in human body is associated with the consumption of liquid content, while over 25 million Nigerians are diagonized to die from highly chemicalized products. Recognizing that water is critical to sustainable development, it concludes that there is an urgent need for increased awareness among leaders so that adequate strategies can be made for development under conditions of severe water scarcity and that there is absolute need for team work between national governments, multilateral bonds, UN agencies, professional associations, the private sectors and development partners (NGOs) etc., if we are to develop and manage our water sustainably. Government should take up the responsibility of providing potable water. Furthermore, there is need for strong policy, legal and regulatory frameworks, more effective implementing organizations and appropriate instruments. This can be achieved principally through strengthening the capacity of relevant institutions and ministries/agencies to be more pro-active in monitoring and compliance. More importantly, as water scarcity intensifies, we must remember that without water, there is no food, and without food, there is no security. However, technological advancement has created a sense that no problem is too big for our collective innovation potential if we invest appropriately in research and development. But we must not ignore or diminish the need for collective action to solve structural and often systemic problems. We also must not underestimate the urgency of the challenge. The cost of inaction can quickly destabilize communities when water is at stake. This is especially important if Nigeria hopes to achieve her developmental priorities of poverty reduction and re-creation of wealthy prosperity for her citizens as envisioned in the "Seven-point Agenda", "Vision 202035 " and SDGs.
\end{abstract}

Keywords: water crisis, teamwork, partnership, sustainability, increased awareness, multilateral bonds, regulatory framework, freshwater resources.
Volume 3 Issue 4 - 2019

\section{Raimi Morufu Olalekan, ${ }^{1,3}$ Omidiji Adedoyin \\ $\mathrm{O},{ }^{2}$ Adedipe Amakama Ayibatonbira, ${ }^{3}$ \\ Babatunde Anu, ${ }^{4}$ Odipe Oluwaseun \\ Emmanuel, ${ }^{5}$ Nimisingha Deinkuro Sanchez ${ }^{6}$ \\ Department of Community Medicine, Environmental Health \\ Unit, Faculty of Clinical Sciences, Niger Delta University, \\ Wilberforce Island, Nigeria}

${ }^{2}$ Department of Geography and Environmental Management, Faculty of Social Sciences, Niger Delta University, Wilberforce Island, Nigeria

${ }^{3}$ Department of Marine and Environmental Management (Prevention) Nigerian Maritime and Safety Administration, Nigeria

${ }^{4}$ Action against Hunger, Yobe State, Nigeria

${ }^{5}$ Department of Environmental Health Sciences, School of Health, Allied and Environmental Science, College of Pure and Applied Sciences, Kwara State University, Nigeria ${ }^{6}$ Department of Civil and Environmental Engineering, Faculty of Engineering, University of Strathclyde, United Kingdom

Correspondence: Raimi Morufu Olalekan, Department of Community Medicine, Environmental Health Unit, Faculty of Clinical Sciences, Niger Delta University,Wilberforce Island, Bayelsa State, Nigeria,Email ola07038053786@gmail.com, morufu.raimi@waldenu.edu

Received: May 28, 2019 | Published: July 09, 2019

\section{Introduction}

Nigerian polarization of its society with an estimated population ranging from 198 to 210 million people and rich in natural and human resources, growing at the rate of $3.2 \%$ per annum, into a large rural sector and a small urban component provides a basis for the inadequate and indiscriminate pressure on existing sanitation and water infrastructural facilities that has resulted in complex emergencies such as 2.2billion people lacking access to safely managed water and 4.2billion lacking safe sanitation, both in the urban and rural areas which could lead to non-observance to relevant international humanitarian law. For instance, over $65 \%$ of Nigerian population who live in the urban slums and rural areas are most neglected and deprived of basic services as well as other modern infrastructural necessities that are essential to the maintenance and promotion of good health. Hence the deliberate, purposive and indiscriminate refusal of facilities essential to societies is an indication of violation, its supply is a major factor for consideration in the health of any community. ${ }^{1,2}$ Despite its rich natural resources, more than two-thirds of Nigerians are poor with an estimated 70 percent of the population lived in poverty 
with a per capita income of less than $\$ 1000$ per annum and a life expectancy of 45 years. ${ }^{1,3}$ The literacy rate is around 40 percent and doctor-patient ratio is about 1:1,000, which make it one of the worst health care systems in the world. The public sector is very weak, and stability of the country is threatening to crumble by corruption. As such, compared to the developed world, there is total collapse of governance in Nigeria.

Schematically, as a resource, water is an assert; as a flood, it is a threat; as it becomes scares, it causes Drought. Man can survive for 5 weeks without food but maximum of 5 days without water. It is the most important raw materials for mankind called "Liquid Gold". It is mainly because of the magical substance only that earth's temperature is maintained reasonably uniform at an average of $16^{\circ} \mathrm{C}$. Man needs about 150 to 300 liters of water every day for domestic purposes such as drinking, cooking, washing utensils, bathing, flushing toilet, aircooling, gardening etc. ${ }^{4-7}$ Water has a number of properties to life that are of critical importance to life and the environment. ${ }^{7}$ Water is the only inorganic liquid that occurs naturally. It is also the only chemicalized products on this planet that occurs naturally in all three states of matter viz: solid, liquid and gaseous. ${ }^{7,8}$

The world is running out of clean, fresh water to feed and nourish a growing global population, ensure sustainable human development, and maintain the health of our planet. Ringler et al. ${ }^{9}$ reported that nearly 2.4 billion people, which is more than one-third of the world's population at present live in regions with scarcity of water, and projections indicate that by 2050 more than half of the global population could stand at risk due to water stress. Competition for water among its many users including food and agriculture production, the environment, energy, industry, and individual consumers is going to intensify. Increased competition over highly stressed, shared water sources, combined with weak governance and increased weather variability, can lead to migration and even violence. Failure to treat water as a strategic, valuable, and limited resource will accelerate water insecurity, even for historically water-secure populations, and may threaten the economic and political security of nations, including the United States. ${ }^{10}$ Interestingly, water touches every aspect of our lives: food, health, environment, industry, and leisure. The competition for water resources is increasing between people and the natural environment as well as between cities and rural areas. According to Ringler et al. ${ }^{9}$ the world's population is likely to rise to 9.8 billion by 2050 , with 86 percent living in underdeveloped nations as well as 70 percent living in fast developing urban regions. Hence, Wada et al. ${ }^{10}$ projected that by 2050 , there will be increase in the global need for water by 30 to 50 percent. However, the economic and social development has led to rapid deterioration of water quality and caused a counter effect on its already low availability.

Water, the utmost natural abundant compounds that is found in the universe covers approximately three-quarters of the earth surface. Despite the great abundance of water in the universe, a number of influences limit the volume of water that is utilized by humans. In Table 1, the ocean and other saltwater bodies that is not freely usable for most purposes has $97.3 \%$ of the total water on earth. Out of the $3 \%$ that remains, a slight above $2 \%$ is locked up and found in ice caps and glaciers. The remaining $0.62 \%$ of fresh water is found in lakes, rivers and ground water which is available for domestic and agricultural uses and livelihood support is utilized by humans for sustenance. Morufu and Clinton, ${ }^{5}$ Olalekan et al. ${ }^{7}$ reported the use of water for industrial and municipal purposes. Khitoliya ${ }^{11}$ reported the need to monitor water supply throughout by taking all aspects in ensuring right water quality in order to maintain, provide and protect minimum water requirements for natural ecosystems. Water exist in diverse forms across the universe such as river water, spring water, rainwater and mineral water. Rainwater is considered the purest form of natural water. In excessive heat, evaporation of water occurs from the sea surfaces. According to Khitoliya, ${ }^{11}$ Morufu and Clinton, ${ }^{5}$ water vapours that arise from water surface are directed by the winds onwards.

Table I World water distributions

\begin{tabular}{lll}
\hline Location & Volume, $\mathbf{1 0 1 2 \mathbf { m } ^ { 3 }}$ & $\%$ of Total \\
\hline Land areas & & \\
\hline Fresh water lakes & 125 & 0.009 \\
Saline lakes and Inland Seas & 104 & 0.008 \\
Rivers (average instantaneous volume) & 1.25 & 0.0001 \\
Soil Moisture & 67 & 0.005 \\
Ground Water (above depth of $400 \mathrm{~m})$ & 8350 & 0.61 \\
Ice caps and glaciers & 29,200 & 2.14 \\
Total Land Area (rounded) & 37,800 & 2.8 \\
Atmosphere (water vapor) & 13 & 0.001 \\
Oceans & $1,320,000$ & 97.3 \\
Total all locations (rounded) & $1,360,000$ & 100 \\
\hline
\end{tabular}

Adapted from Khitoliya."

\section{Water and the living environment}

The origin of water preceded the evolution of life. In fact, the reactions that make up life, such as the synthesis of proteins and nucleotides, occurred in the aqueous medium. It is for this reason that water forms a part of biological structures. For example, water plays an important role in maintaining protein structure. Water molecules are bound to the protein chains at varied locations through hydrogen bounding. These hold up the proteins in their peculiar folded conformations. Without the folded conformations, the proteins would have been unable to perform their specific functions. ${ }^{8}$ The water content of an adult human being is $65-75 \%$. Table 2 shows that a normal adult person consumes two and a half liters of water every day and loses an equal amount. The daily gain of $350 \mathrm{mi}$ water, due to glucose oxidation, result from the reaction.

Table 2 Daily balance sheet of water of an adult

\begin{tabular}{ll}
\hline Gain(ml) & Loss $(\mathbf{m l})$ \\
\hline Drinks: 1300 & Respiration:400 \\
Food:850 & Evaporation:500 \\
Glucose Oxidation:350 & Excretion: 1600 \\
Total:2500 & Total:2500 \\
\hline
\end{tabular}

\section{$\mathrm{C}_{6} \mathrm{H}_{12} \mathrm{O}_{6}+6 \mathrm{O}_{2} 6 \mathrm{CO}_{2}+6 \mathrm{H}_{2} \mathrm{O}$}

This reaction liberates about $8000 \mathrm{KJ}$ of energy which utilized by the body for performing essential work. Had this energy been dissipated as heat, the body temperature would have risen by 26degrees and would have resulted in death. ${ }^{8}$ 
Plants derive their energy from the reverse reaction, this is,

$$
6 \mathrm{CO}_{2}+6 \mathrm{H}_{2} \mathrm{O} \mathrm{C}_{6} \mathrm{H}_{12} \mathrm{O}_{6}+6 \mathrm{O}_{2}
$$

The equation above represents photosynthesis and it explained how carbondioxide react with oxygen in the presence of solar energy (sunlight) to produce glucose (starch) and oxygen. The levels of carbon dioxide and water in the biosphere are maintained by reaction. The large surface tension of water (73dynes $\mathrm{cm}^{-1}$ at $293 \mathrm{~K}$ ) and its ability to wet surfaces are the basis for the capillary action, which carries water to the leaves of plants and trees. Water has a maximum density at $277 \mathrm{~K}$, a little above its freezing point. Thus, lower density is attributed to ice than liquid water. ${ }^{12}$ It, therefore, floats on the water surface and freezing of aquatic systems occurs from surface downwards. Unlike, the solid state of other substances is denser than the liquid state. ${ }^{13} \mathrm{Had}$ water behaved in this manner, the aquatic systems would have frozen from bottom up. As a result, the aquatic life in oceans, rivers or lakes would have perished in the winters. ${ }^{8}$

\section{Water and the non-living environment}

$71 \%$ of Earth's surface contains water, which consist of mostly salty water. The percentage of fresh water is just $2.5 \%$ of which only $1.2 \%$ is found in lakes and rivers. The remaining portion of the fresh water found on earth is held in ice caps and glaciers (68.8\%) or underground $(30 \%)$. The roles of water in weather and climate is of interest. It is the most occurring greenhouse gas in the atmosphere, that accounts for $40-70 \%$ of heat trapped in the earth. Furthermore, water is anomalous and complex. Water is termed the universal solvent as it dissolves a number of substances. Water is said to be polar because it freely dissolves charged or polar solutes. Water also dissolves some non-polar molecules such as aromatic compounds. Nevertheless, water is not a good solvent for non-polar molecules like hydrocarbons i.e. oils, that is why oil and water do not mix. Materials made of molecules of equivalent size and shape is less cohesive than water. Water molecules interact with each other reasonably intensely. Emiliano et al. ${ }^{14}$ reported that water has quite high surface tension values, boiling point, and melting point; in addition, water has density anomalies which manifest in different ways.

Water has a high heat capacity per unit weight. This means that it can absorb relatively large quantities of heat without large changes in temperature. Thus, during summers a large body of water, such as a lake or an ocean, absorbs more heat from the air than the land. An area in the vicinity of the water body, therefore, would have a lower temperature than a distant region. During winters, the temperature of the air drops below that of the water and the aquatic system gives up its stored energy as heat. This effect tends to warm up the air. As a result, the areas surrounding a lake, or an ocean have milder winters. The heat capacity of water that is high allows the oceans to collect substantial amounts of thermal energy. Sodhi ${ }^{8}$ reported that oceans act by way of big thermostats through which the heat energy is often passed to cool regions via currents or waves. Water has a very low coefficient of compressibility $\left(5 \mathrm{pa}^{-1}\right)$ at normal temperatures as well as pressures. Conversely, if water is absolutely not compressible, then the sea level would be much higher by 40 meters, which would reduce the areas where people inhabit by $5 \%$. The high dielectric constant of water makes it an excellent solvent; it is often referred to as the universal solvent. As a result, natural water is never pure, but a solution of substances which come into contact with it. When the number and or concentration of the chemicals entering an aquatic body become so large that the natural qualities of water are altered, we say that the water has become polluted. ${ }^{5}$ The dissolved impurities are not the only ones which make the water stained. The suspended matter is also hazardous. When the aquatic system becomes polluted it becomes mandatory to purify water, so that its natural qualities are restored. However, before water can be purified, the type and nature of the pollutants must be identified. ${ }^{1-8}$ A robust response to this complex picture requires the use of water that supports the ability of human society to endure and flourish into the indefinite future without undermining the integrity of the water cycle or the ecological systems that depends on it.

\section{Conflicts over water}

Humans need water. If it is in short supply, conflicts can arise. Fresh water is one of the most precious of natural resources. Water is available in huge quantities throughout the world, but scarcities can arise on a local level, since rainfall, natural water reservoirs, and demand create an uneven distribution across the globe. A shortage of water can cause conflicting needs to emerge within and between countries. As a result, around the world, fresh water is fast becoming a dangerously scarce resource, driving a surge in fights to secure supplies and fears over rising numbers of deaths in water conflicts. But, water, as you know, is the most important resource of a society, since no life is possible without water. A society can survive without other resources like minerals, fuels, forests, livestock, etc. but cannot survive without water. ${ }^{12}$ So long as sufficient and plentiful of water remains available to fulfill the present and future needs of the society's population, there shall occur no conflict among the populace; but if the available water becomes or likely to become scarce or deficient, then naturally, quarrels and conflicts among its shareholders are bound to arise. Up to a few decades ago, water was generally available comparatively much easily, as compared to its availability in today's times. The basic reason for this shortage is the increasing demand of water due to increasing population, changing lifestyles, and excessive use in irrigation. So much so that the present annual global withdrawal of water (2005) is about $4500 \mathrm{Bm}^{3}$, which is about $21 / 2$ times the withdrawal of the year 1950. Due to increasing demand, the scarcity of water is becoming more and more apparent, particularly in water short countries. At present, about one billion people globally have no access to portable water, the water supplied to others are highly insufficient and erratic. It has further been estimated that more than 30 countries of the world are already facing severe water shortages, while this number is likely to increase to more than 50 by the year 2025. The U.N. has estimated that by the year 2025, nearly 4billion people would experience great water shortages, result of which may cause various conflicts from one country to another in a bid to share water. As a matter of fact, about 100 countries tend to share the waters from 13 large different lakes and rivers. The countries on the up-stream sides may create scarcity conditions for the downstream nations, leading to conflicts and water wars. ${ }^{15}$

Africa, by far, is the most potential continent for such flare ups during the next 25years, simply because countries may compete for accessibility to limited water resources, wars as a result of water scarcity are likely to occur in regions that often share lakes and rivers between one or more countries. Examples of possible flash points are the Nile, Niger, Volta and Zambezi river basins. Ethopia for example is already in great tension with Egypt. Ethopia, infact, is situated upstream of the Nile river, while Egypt, located downstream, is highly dependent on water of Nile river. The Ethiopian government was pondering over the construction of dams on the Nile to utilize 
its water for itself. This led to severe opposition from Egypt. In the dying years of the previous Ethiopian government, the tension between Ethiopia and Egypt has increased so much, that a water war looked imminent. There is another possibility of a water war between Botswana, Namibia, and Angola. The river possesses a great potential for a water conflict between these neighboring countries, who are the authorized shareholders of this river.

As far as India is concerned, it shares Ganga river with downstream Bangladesh; the Indus river with downstream Pakistan; and Brahmaputra with upstream located China. Moreover, just after the Partition, had entered into a conflict with Pakistan on sharing of Indus waters; but the problem was sorted out with Indians magnimity by international arbitration on the basis of Indus Commission Report, leading to signing of Indus water Treaty in 1961 (to be effective wef 1.4.1990). According to this treaty, the water of Sutlej, Beas and Ravi (all tributaries of River Indus) were allocated to India for unrestricted use; while the waters of Indus, Jhelum and Chenab (other tributaries of Indus) were allocated to Pakistan. The India was allowed to use the existing irrigation facilities and to develop an additional $0.28 \mathrm{Mha}$ from these three rivers, but on payment of a huge cost amounting to 62.6 million Pounds to Pakistan. India has, similarly, entered into an agreement with Bangladesh on sharing of the water of Ganga river at Farakka on 05.11.1977. However, prior to signing of this agreement, a lot of tension and bad blood had been generated with that country (i.e., East Pakistan at that time) on the issue of construction of Farakka barrage. Signing of such international agreements is absolutely necessary for reducing the possibility of water wars between different nations. As in some other countries, there also exist some disputes between certain States of India on sharing of river waters passing through the beneficiary States. The continuing conflict between Karnataka and Tamil Nadu on sharing of Cauvery waters is one of the most prominent of such Inter-state river water disputes in the country. This dispute continues as Karnataka due to its own compulsions and necessities, sometimes fails to release enough water into Cauvery River to quench the thirst of the downstream located Tamil Nadu, leading to political mudslinging and conflicts. All such conflicts and infightings have a great potential to convert into bloodsheds due to internal riots, battles, and wars. Another prominent example of such continuing inter-state river water disputes of India is the conflict between Haryana and Punjab on the issue of the construction of $201 \mathrm{~km}$ long Sutlej-Yamuna Link Canal (SYL Canal), which shall divert waters of river Beas (after it outfalls into Sutlej) to Yamuna, so as to enable Haryana to utilize its share in the Beas waters as awarded to it by the Ravi-Beas Water Disputes Tribunal (also called the Eradi Tribunal). This link canal, as you may know, is lying incomplete since long, as the State of Punjab has not allowed the construction of $121 \mathrm{~km}$ long portion of this canal through its territory, due to its own compulsions. The terrorists during the days of military in Punjab in 187-1993, actually, made SYL an issue and opposed its construction on the plea that SYL will cause immense and irreparable harm to the farmers of the Punjab State, as they will be deprived of their precious water, ${ }^{15}$ (Table 3 ).

Table 3 International water disputes

\begin{tabular}{|c|c|c|}
\hline River & Countries in dispute & Issues \\
\hline Lake Chad & Nigeria, Chad & Dam \\
\hline Okavango & Namibia, Angola, Botswana & Water diversion \\
\hline Nile & Egypt, Ethiopia, Sudan & Siltation, flooding, water flow/diversion \\
\hline Euphrates,Tigris & Iraq, Syria, Turkey & Reduced water flow, salinization/International quotas, Salinity level \\
\hline Jordan, Yarmuk, Litani, West Bank aquifer & Isreal, Jordan, Syria, Lebanon & International quotas/Water flow/diversion \\
\hline Indus, Sutlei & India, Pakistan & Irrigation \\
\hline Ganges-Brahmaputra & Bangladesh, India & Siltation, flooding, water flow \\
\hline Salween & Myanmar, China & Siltation, flooding \\
\hline Mekong & Cambodia, Laos, Thailand,Vietnam & Water flow, flooding \\
\hline Parana & Argentina, Brazil & Dam, Land Inundation \\
\hline Lauca & Bolivia, Chile & Dam, Salinization \\
\hline Cenepa & Ecuador, Peru & Water allocation \\
\hline Rio Grande, Colorado & Mexico, United States & Salinisation, waterflow, agrochemical pollution \\
\hline Rhine & France, Netherlands, Switzerland, Germany & Industrial Pollution \\
\hline Maas, Schelde & Belgium, Netherlands & Salinization, Industrial Pollution \\
\hline Elbe & Crechoslovakia, Germany & Industrial Pollution \\
\hline Danube & Hungary, Slovak Republic & Industrial Pollution \\
\hline Tagus & Spain, Portugal & Water allocation \\
\hline Szamos (Somas) & Hungary, Romania & Industrial Pollution/Water allocation \\
\hline
\end{tabular}

Adapted from Carla, ${ }^{36}$ 


\section{Global water crisis}

Water is an indispensable and irreplaceable resource for development. In fact, the welfare of every society is inextricably linked to the sustainable exploitation of water resources. While, humans are faced with both natural and social emergencies including crises of water, which is very vital for our survival, health, dignity and sustenance on this planet. Worldwide, the demand for this vital resource has soared considerably owing to rapid economic development and increased population growth. With the rise in population across the globe comes the need to grow more food and thus the need for more water for agricultural purposes. This has translated into overexploitation of water resources in some parts of the world over the years resulting in depletion of surface and groundwater resources in some instances. The impact of water crises cuts across all regions of the world and no region will be spared, as it touches every aspect of life on earth, beginning with children's wellbeing to the ability of nations to provide food for her citizens at large. The rate of water supply is reducing as demand and need for water increases in an unsustainable manner. ${ }^{8,16}$ With a global population of 26 billion, $19.45 \%$ lack access to safe drinking water and $50 \%$ live under unsanitary or unhygienic condition.

Due to inactivity or slow actions by those in authorities, there will be increase in world water crises level years to come due to increase in human populations that demands more water use. For now, some 2.2 million people still lose the battle of life each year by succumbing poor sanitation and water related diseases that affects 6,000 children dying daily from preventable diseases that could be stopped through safe water and sanitation. ${ }^{1,17}$ Around $40 \%$ of the global population presently lives in regions with medium to high water stress and it is likely that two-thirds of the global population (nearly 7billion) will likely live in areas facing such water stress, ironically, as the world's fresh water system get severely degraded through pollution, water use worldwide has increased six fold over the last 100years, a figure which more than doubles the already precarious rate of population growth. The extent of pollution of water can be better imagined when it is considered that $90 \%$ of sewage and $70 \%$ of industrial wastes are discharged untreated, often polluting the useable water supply. Consequently, patients who suffers from water-borne diseases are more than half of those who are admitted to hospital beds across the globe. ${ }^{7,18,19}$

Globally, the current water supply picture has been alarming despite the unprecedented advances in the last decades. Fresh water supply is facing intense and unsustainable demand from users of all sorts including farmers, which have to compete for water with urban dwellers and industries. A situation of total lack of water, which may prompt a country to go to war to acquire streams or rivers, is not very far in sight. In the Sahelian region and drought prone areas of the globe, there is a strong association between water availability and foods production..$^{20}$ It is an undeniable fact that poverty undermines provision of good water supply. ${ }^{1,19}$ Moreover, lack of essential benefit of hygiene, sanitation, water and hygiene to all persons remains a barrier to growth, and a root cause of unending poverty. ${ }^{1,19}$ If good water is synonymous with developed societies, then little or lack of it or poor quality is associated with poverty and deprivation, which is the bane of the third world countries. ${ }^{19}$ That is why most of the poor people in the world are frequently sick as a result of unwholesome water utilization and poor hygiene. ${ }^{18}$ Since life expectancy is a cumulative event in an environment, the shear sustained frequency of childhood diseases and afflictions occasioned by malnourishment, poor mental and physical development and timely death stem from poor hygiene and contaminated water. ${ }^{1,8,18-20}$

In many developing countries, i.e. Nigeria (Abuja, Borno, Yobe, Niger, Adamawa, Kano, Bauchi, Sokoto, Gombe, Zanfara etc.) women and children are seen roaming many miles in search of water, sapping their energy, and dissipating their time. Almost one- thirds of the globe still resides in squalid environments, smell and disease at the doorstep and being imprisoned by hygiene related illness and ignorance. ${ }^{1}$ These are also countries of high population growth rates. Economically, the poor are still spending more on hygiene-related and water-borne diseases, weakening more ill economic indices and perpetrating continuous poverty. It is expected that more funds be committed to water development projects particularly in the third world countries and the significance of water assets as a defense against universal poverty should remain more effectively addressed. ${ }^{20}$

\section{The nature of water crisis and its prospects}

In a move by Nigeria with other African countries in promoting the vision of Africa in respect to water provisions, its approach to natural resources authority and additional growth gives rise to crisis of water and rural poverty. Omoweh ${ }^{22}$ reported water crisis as creating a foremost public policy task for policy and decision makers, development practitioners, scholars and development partners i.e. (NGOs). In most rural population, crisis of water is associated with land crisis, usually because livelihoods of those in rural areas are often linked to land, likewise most lands belong to Government of Nigeria. Daniel ${ }^{23}$ reported that history of water crisis is not new in Nigeria, water crisis is embedded in the Nigerian state and during the colonial days. It is the flaw created by state's capitalist improvement in natural resources and service provision.

Water being a vital resource of nature is being conceptualized by the State to a great extent as an asset to be exploited to create capital and other open merchandise, with next to zero thought to enable sustainable and effective restoration. ${ }^{24}$ Actually, scholar such as Hardin critiqued that, water being a shared resource product or reserve, needed copyrighted character its lack that resulted in water tragedy. ${ }^{25}$ Hardin's critics like those of Bromley and Cernia described his judgement as not only basic culturally and socially, yet generally untrue. ${ }^{26}$ Okoth-Ogendo, contended that Hardin was insensible to standard laws, traditions in addition to customs of Africa; in addition, the African misfortune goes further than its unrestricted actions to incorporate the adoption, dominance and sabotage of the African majority by the colonists. Common shared reserves or resources like water had a registered character, as there are different traditional societies, different social levels, and native knowledge needed in organization, conservation, renewal and governance, as shown by such necessities of most general population. Omoweh ${ }^{22}$ reported that the policy of colonial capitalist has influence on the state through granting sole ownership, rights to water, rights to access to water asset by the state, which proceeded within the post-frontier period. ${ }^{22}$

Besides, hydrological resources are complexly linked to land that the state likewise practices single ownership and control under the 1978 Nigerian Land Use Decree that was taken out of 1914 Mineral Act. The Land Use Decree of 1978 has created move for land into the swamps, lakes, creeks and wetlands in most Niger Delta areas, a region for oil exploration, production, transportation, and storage. Water Decree of 1993 also assigned the single ownership of water, 
both optional and essential water, surface and underground water Omoweh ${ }^{22}$ reported that the Nigerian state according to Water Decree of 1993 has been assigned the single ownership of water, both optional and essential water, surface and underground water, and is being authorized to manage waters of Nigeria for the production of hydropower and to construct river basins but due to private interest the management and sustainability becomes a challenge.

Weak and erratic governmental policies and interventions on infrastructures crucial for sanitation and water facilities often led to crisis of water, scarcity and inadequacies which gives rise to illnesses and other hazards that affects the poor people in rural and urban centres. Being a public service offered socially, the philosophy of the state is persistent in the way of its predecessor in the area of urban-based development, accounting for the setting up of water systems typically within different States and a small number of semiurban areas like Ogbia, Kiama and Imirringi while abandoning the rural poor areas. Around Yenagoa, the Capital of Bayelsa State, an estimated 20liters of water is consumed per head per day for top government officials including State House of Assembly members and commissioners which is against the recommended 70liters per head per day. However, water consumption is put at 5liters per capita in the rural areas, as rivers, swamps and creeks continue to be the chief water sources with very limited water schemes. ${ }^{1,7}$ Surface and aquifers water contamination by oil companies operating in the Niger Delta resulted in soluble manganese and iron that dissolve in water which has contributed to water insecurity in most Niger Delta states. .- $^{5-}$ Omoweh $^{26}$ reported that crisis of water has become a national issue in Nigeria, simple because only 40 percent of the coverage of water nationwide is for the key cities such as Ibadan, Abuja, Kano, Port Harcourt, Kaduna, Maiduguri and Lagos with a despondent 5 percent found in some local government areas.

Governance predicament has been attributed to water crisis in most States in Nigeria and it signifies a greater issue profoundly established in capitalist improvement in God's created resources which is being cut-edged by Nigeria and her foreign capital. In practice, the membership of the board in the oligarchs, the bureaucracy, the public authorities of the local and external authorities, the legislature of the institutions and the donor to present the loans, as well as the electorates and the users. The progress of parochial interests and specific terms. ${ }^{22}$ Oppression and violence have become an outcome of the distorted manner in which the Nigeria state is constituted, and this describe why actors in the state and political elites are unwilling to democratize natural resource governance and development issues in general. ${ }^{23}$ Democratizing water resource management therefore involves disputes which for this purpose, the authorities in Spain set up the Water Court in Valencia in 1831. To resolve disputes with water, in the same place up to now. However, in the case of unauthorized access to documents related to the development of water resources. ${ }^{22}$

\section{Reactions to water crisis and responses}

\section{Water resources governance and democratization}

More importantly, having an idea of the political economy of the prolonged upheavals in Bayelsa state and in other oil-rich communities in the Niger Delta is to determine if they are really replenished by the democratization of the governance of natural resources, including water resources and land. ${ }^{22}$ To understands the political fundamentals of the events in relation to people, who bear the brunt of the water crisis and rural poverty and having alternative strategies which have been developed to create persistent unrest for self-determination, social justice and equity, ownership and control of natural and natural resources. Fiscal federalism since the late 1950s. Since 1980, when oil companies became aware of environmental pollution, that they are even bigger, they have grown. as much as most oil sites are located abroad. ${ }^{22}$ Moreover, security of water and the promotion of development in the rural areas guarantee not much success Instead, the state and oil companies continue to pollute environmental resources, thereby increasing the trend in rural poverty. However, there is no indication that water insecurity is inverted, largely because of the inadequacy of the crisis by agitators. The majority of the people involved in the struggles have not really understood the debt crisis of the state's perpetual by water crisis and its effect, a governance crisis and a fraction of political elites that include agitation. In part, the opportunity to review democratization and the stocktaking of policies and resources for politics, society and the economy, without ending the emphasis on water crisis. According to Omoweh ${ }^{22}$ he reported that, the Nigerian elites are not oriented towards the democratization of land governance around the source causing the crisis of water. Although, some architects who contributed to the exploration of resources have helped re-awaken the agitation for resource control in 2000, particularly, the governors of Akwa Ibom, Bayelsa, Delta, and Edo and the southern geopolitical zone, where approximately, 97 percent of the country oil has been produced. In the meantime, once position can be maintained and control the resources by groups and organizations involved in activities in the Delta region. ${ }^{22,27}$ Worse still, democratize the governance of natural resources, in relation to the question of whether the People's Democratic Party (PDP) or All Progressive Party (APC) and other pressure group extraction of the Niger Delta in general. The governance of the resources and the recruitment of poor and peasant rural people for the development of rights and a natural resource governance for the poor. All this poses a great risk for the struggle, because as soon as the current political power ceases to be the governor or to be excluded from the political power of the State, the struggles could lose its rhythm and its importance, Omoweh. ${ }^{22}$

Regarding rural poverty, especially for the peoples whose major occupations are fishing and farming. ${ }^{28}$ with no clear signs that the water crisis in Bayelsa state is abating. Indicating crises of water to be governance crisis and coupled with the fact that the crisis of the Nigerian state cannot be effectively dealt with by the state government alone. For other reasons, there are other forces outside the State and even the federal government including local private sector and foreign oil companies would like to maintain the most active position in the Niger Delta. This is a part of the internationalization of the region and of the rural community in the oil rich zone of the South-South..$^{22}$ More importantly, environmental resources, in particular land, water, oil and gas, forest resources have characteristics that make their management problematic. It combines local, national issues and international levels, raising issues that can help reduce poverty, participation, accountability, transparency and integration at all levels of governance. In particular, water resources are slowly growing, offering different values to different people and providing a long-term repository of values for people and society. But these environmental resources are easily destroyed by an unsustainable policy of exploitation and a framework for their selfish interests, which is evident on the path the state has taken to exploit resources. They also cannot be assigned a monetary value; nor can the financial value of poverty be increased, which is accelerated after the destruction of these resources by state and oil enterprises. Because the state imagines oil-producing areas as 
minefields, state and oil operations even annihilate the methods of local resource management that are better, better than Western policy and biodiversity management, conservation and protected areas projects. ${ }^{27}$ Positioned in this framework is difficult to promote local growth. With wetlands, such as swamps, streams and rivers, also biologically dead due to constant environmental pollution, combined with the killing of fish and planktons, fishing, which is the dominant occupation in coastal areas of the state, is systematically decreasing. ${ }^{5,6,28}$ Pollution in the continental shelf and oil locations in Deepwater destroyed the hydrological regimes of the rivers, thus blocking the process of aquatic organisms' renewal. The shortage of land and landlessness, where agriculture is the main occupation, forced rural farmers to cultivate wetlands, i.e. the Marshes, and the extension of the border caused mass floods in the rainy season. ${ }^{28}$ Not surprisingly, the establishment of the Niger Delta River Basin Organization [NDRBA] in 1981. Among other such organizations, allegedly to use water in the Delta region was a huge failure. It was created without the introduction of appropriate mechanisms and strategies to stop gas combustion, oil spills and other forms of environmental pollution. ${ }^{5,6}$

Food gathering such as rural water and forestry resources like snails, water snails, periwinkles etc. among the Bayelsan village is not barbaric but represents a sustainable poverty reduction strategy for the rural population. Such was the case when oil companies started operating in the Niger Delta. As a result, food collection is no longer protected as a local life strategy, especially because the country's resources under gas and oil spills, as well as untreated landfill and wetlands, swamps, have been permanently destroyed. Indeed, poor water resource management has become the focus of rural poverty. ${ }^{7,18}$ However, some developmental partners, such as the Chicoco Movement, the Environmental Right Action, the Democracy and Development Center, have been involved in the research and promotion of the Niger Delta region, hardly created programs and projects on key issues of rural development. Members of the international community, such as the United Kingdom's International Development Department, the United Nations Development Program, UNESCO and USAID, who showed their interest in rural development and ensure minimum funding, also did not raise concerns about the origin, nature and dynamics of rural areas. Poverty and helping development partners i.e. NGOs to strategize for its reversal. It is in order to examine the responses of the state and other development partners and agencies towards crisis of water in the context of current scenario.

\section{Politics of water schemes}

Access to quality drinking water is a subject of immense interest in the developing world where 2006 figures indicate that only 58 per cent of the population have access to potable water as compared to an aggregate global coverage of 89 per cent. ${ }^{29}$ The concern commonly expressed about the disparity in good drinking water between the developed and developing world is founded on the obvious connection between good drinking water, on the one hand, and good health and improved livelihoods on the other. The United Nations (UN) World Report 2 notes that poor water quality is a major cause of poor livelihood and health and estimates that the provision of access to safe drinking water, sanitation and hygiene could save about 1.6 million lives annually. ${ }^{30}$ Moreover, the WHO notes that "management of small community drinking water supplies has been universally identified as a critical issue for sustainable development and health, and an issue that requires significant attention to protect community health and to ensure the water-related Sustainable Development Goals (SDGs) can be met". ${ }^{17}$ On livelihoods, Butterworth ${ }^{31}$ reveals that access to potable water eventually translates into poverty alleviation and improved livelihood. Since, water is a public good and service as an infrastructure. The process of bringing water to people is based on a range of factors, including feasibility studies, sample analysis, planning, implementation and renewal, wells depth, adequate structures, from pumps to their capacity, to water treatment plants and alum, chlorine and other consumables, air tanks, pipes that carry water to end users, restoring link between prices and quality of water services, the right manpower/skill, building the capacity of local authorities, improving monitoring and benchmarking of the water, staff quarters and vehicles. Similarly, Bayelsa state government, federal government agencies, oil companies, and development partners i.e. donor agencies have been engaged in providing safe water in most states in Nigeria as part of corporate social responsibility or creating shared value. ${ }^{22}$

\section{State level (a focus on bayelsa)}

Although, the state government of Bayelsa has made great efforts to deal with water crisis in the state, as clearly stated in its decision to refine fresh water. More than N4billion has been used in water supply for people since 1999. Still, the persistence of water and water shortages, at the level of government, production and delivery of water produced have been politicized that they lacked transparency, accountability and have nourished poverty. It is a government crisis: The Bayelsa Water Board is a statutory public agency created to produce and supply water in city and rural areas throughout the state, but the Water Board hardly ever performs its legal functions. rather, it operates a water scheme built via the Ministry of Public Utilities and Rural improvement. The provision of safe drinking water to people in the rural and urban areas is still a milestone and yet to be democratized. ${ }^{22}$ Government, for example, plays both coveragemaking functions and implement policies. Without consulting with three (3) key agencies under the Service, namely, Water, electricity and Rural improvement, the govt department awards all contracts for water schemes to Hydro production and Engineering organization. The tendering system is constrained to the corporation, which offers the water pumps, overhead tanks, remedy flora and consumables, installation of transformer. After the water scheme is constructed, the Ministry then instructs the Water Board to operate it. One of the obstacles of the Water Board is that, it's far forced to operate a water scheme that it does not recognize the potential of the water pumps, in which they're made, potential of the tanks, the population it is supposed to serve, no preservation finances etc. As a result, while greater water schemes are being built inside the nation, the manufacturing of water stays grossly insufficient and progressively becoming non-existence non-life. ${ }^{22}$

\section{Yenagoa water scheme}

Water scheme in yenagoa is one of the oldest of all schemes in the state, followed by when Yenagoa was once a UAC depot, until it became the capital of the city. ${ }^{22}$ The 600 gallons of water flows for 18hours a day, given steady energy supply, which is hardly assured, because the state is yet to be linked to the country wide grid system. Conservatively, this translates into 2.3 million liters of water every 18 hours, approximately a day. ${ }^{22}$ Yenagoa possess other water scheme such as the Swale water scheme. It is made with 6gallons of water of 150 cubic meters, totaling 900 cubic meters, translated into 
900,000 liters of water. Therefore, every day, water deliver to Yenagoa is 2.3 million and 900,000 liters, totaling 3.2million liters of water. ${ }^{22}$ But, Yenagoa total estimated population is 1,992,000 (2010 projected population) with a land mass of $11,007 \mathrm{~km}^{2}$ and given a daily basis of 70liters a day, which will translate approximately to 105 million liters of water per day, against the production daily total of 3.2million liters/ day, at an average of 20liters per person. That is simply an aspect of the value of water crisis in urban water delivery, despite the 20liters/ individual water deliver, the locations absolutely furnished consist of: Ovum vicinity, including the Government House, House of Assembly and Commissioners Quarters. ${ }^{22}$ Other water schemes within Yenagoa, included: Etegwe water scheme, Igbogini and Kpansia water initiatives (Figure 1), with every challenge deliberately aimed at solving the scarcity of drinkable water within the various quarters within the state which form part of the political crisis of water problems. However, water delivery in the state capital is still grossly inadequate despite increasing private boreholes, as the principal supply of water, which is not treated, regardless of the heavy presence of iron and manganese inside the water. ${ }^{5-7}$ Traditionally, 25litres gallon of water is sold by water vendors at an average of N50.00. The hand-dug well and the stream are still the predominant source of water for the general public of the urban dwellers. ${ }^{7}$ While, the 1999 DSP water initiative brought about increased personal initiative for water distribution geared toward selling water to the residents of Yenegoa and its instantaneous environs. It started with 10 tankers of 3000 liters capacity. Conversely, lacked price range for maintaining the tankers grounded more of them. In the year 2004, it folded up and not much has been done till date. ${ }^{22}$

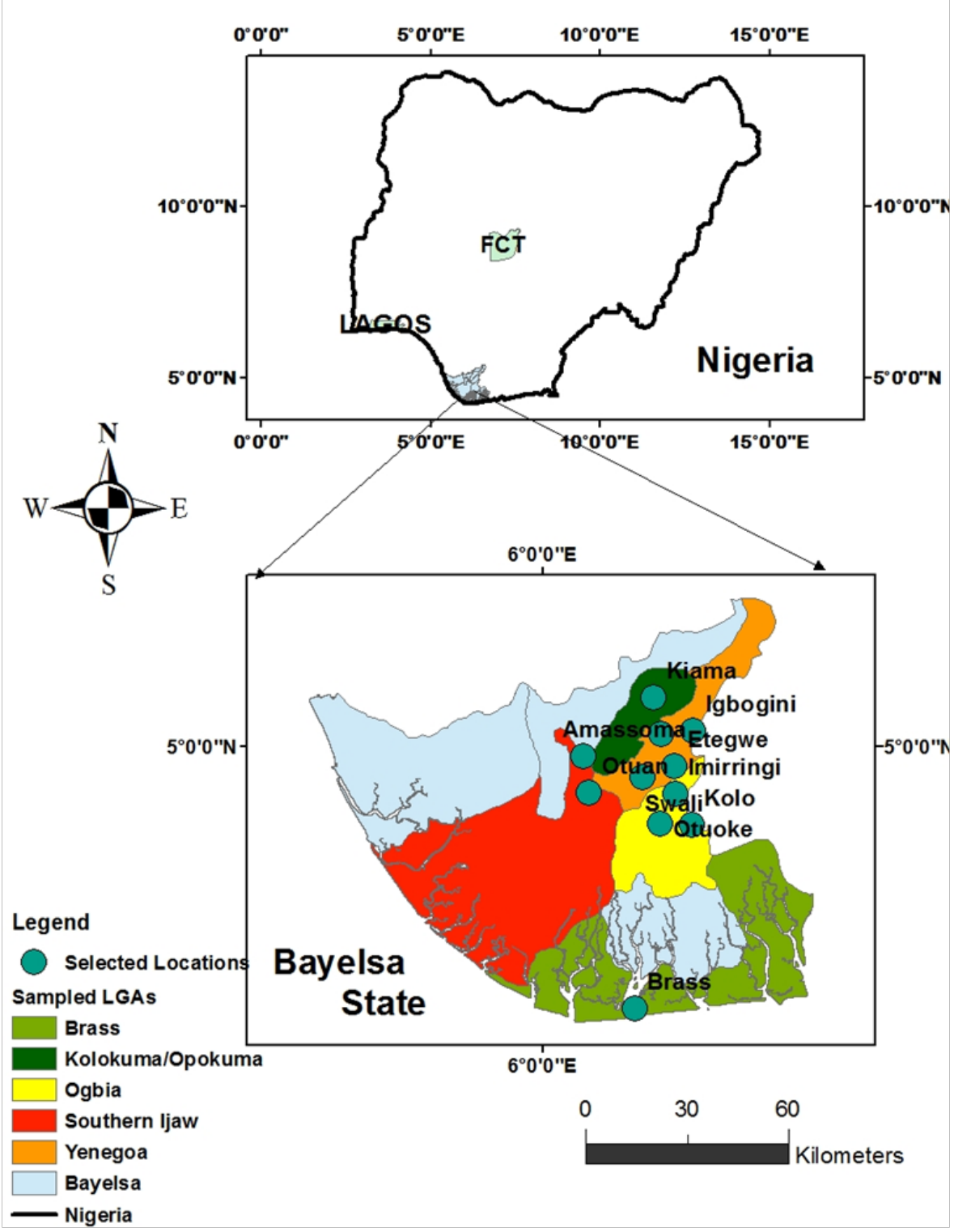

Figure I Map showing selected water schemes in Bayelsa state, Nigeria.

\section{Public and private semi-urban and rural water schemes}

Apart from Yenagoa, there are water projects located in semi-urban and rural communities. The 8LGAs and 24 state development centers have some form of public or private water management schemes, but not all are equipped with water treatment facilities. These water projects are still in various stages of development, some of which are about to be completed and others still in the process of being implemented, under construction and old ones being rehabilitated. 
One of the consequences is that drinking water is still very scarce and insufficient in the countryside. ${ }^{22}$

Firstly, public water projects that is functioning, including the Kolo water project, which produces about 3,000 liters for 8,000 people and those of Oruma under Ogbia LGA and the skeletal city of Odi, and those that will soon be completed in the Southern Ijaw LGA (Opomowei), located in Perembiri, Amassoma, Eseomi and Otuan (Figure 1). Secondly, the category of water projects tested, including projects in Sagbama LGA communities, namely Essozui, Okolobiri and Tombia, is expected to produce 6000liters. The Sagbama water project includes a water treatment plant and produces about 5,000liters of water. ${ }^{22}$ Thirdly, remediation plans are being restored and one of them is the Okolobiri water projects. Fourth, water-related projects that are still largely projects include the Kiama Water project as part of the Kiama, Agbobini and Otuoeke watersheds under the Ogbia LGA; The Peretorugbene and Anyalobiri water projects under the Ekeremo LGA. Alternatively, the category includes water projects for public-private partnerships. Brass water facilities, the only saltwater refinery, produce about 10,000liters of water for about 9,000people a day. Originally, it was a project of the Rivers State Government and AGIP because the company's oil terminal is located in the city of Brass. However, when the state was split in two, Bayelsa and Rivers, the agreement passed into the hands of the Bayelsa State Water Board. Agip funds the water project, while the Bayelsa Water Boards provide technical staff to implement the project. ${ }^{22,27}$ The sixth category of water bodies can be seen as the response of the state and oil companies to persistent unrest among the population and groups concerned about the underdevelopment of oil-producing communities. As a public agency, such as the Niger Delta Development Commission (NDDC), the Ministry of Niger Delta etc., have been accused of providing basic social and physical infrastructure in the Niger Delta. Drinking water was one of his priority projects. However, as a microcosm of the state, projects are largely spoiled by corrupt practices and poor work. An example is the Bilogo water project, which has been commissioned but is being thrown into the trash for lack of funds for maintenance. Another example is the Ametolo Water Project, Southern Ijaw LGA. Launched by Shell, NDDC, OMPADEC and finally UNDP. The project nevertheless has been abandoned. However, the Shell water supply project in Imirringi, 10,000liters of water for about 9,000people a day, is working. But it was built to calm the nerves of excited host communities; however, the company has been burning gas day and night for 50 years, polluting the environment. ${ }^{22}$

Lastly, the international community efforts to remedy the water crisis which UNICEF has expressed interest in educating rural residents about water and sanitation and cooperating with the state in setting up water and sanitation programs and projects. The World Bank has trained, built and strengthened the capacity of the State Water Management Authority for the commercial management of secondary water supply projects in the state, particularly in a state severely affected by a water crisis. The water project begun in 1998 , the Bank provided the necessary funds for the construction of the current Yenegoa Water Office building, provided that all computers and other technical assistance were inherited by Alemeseyia in 1999 . However, nothing was done, mainly because it was difficult public policy on water to implement in a state affected by a water crisis. The European Union and Shell have promised to build water treatment plants, but this has not happened yet. ${ }^{22}$ The various water supply systems described above represent important efforts to address the inadequate production of water.

\section{Solution to water crises}

\section{Partnership building to protect health from water crisis for public goods}

The concept of public-private partnership (PPP) has drawn attention to the policies over the past few years and is progressing as a matter of importance for development programs in many parts of the world, especially in drinking water supply for external goods. Partnerships offer the opportunity to consolidate and share best knowledge and practices, experience and capacity of experts, institution and countries around the world and to bring their expertise to bear on health development issues. Environment health professionals should forge partnerships with other institutions (local and national) on best practices to protect health from water crisis. ${ }^{32}$ Water supply, including to meet unnecessary needs, is a property that is important. In the world, the supply of these properties to Nigerians, and even poor in developing countries, is an urgent policy challenge. Of course, drinking water is associated with social and private cooperation: this entails a complex interaction of public funding and public infrastructure development and robust response to this dynamic interaction between public interests and private participants which is not and is part of the process of providing good quality water. These contributions will provide public funding and background research, to private investment through the infrastructure and management capacity needed for effective infrastructure and product development, or to share research and development features. Thus far, all States, donors, the private sector, universities and research organizations concerned must act vigorously and coordinate to strengthen interventions and to prevent unnecessary loss of time and productive life. States and partners should work together to take advantage of current global dynamics for sustainable access to water for all and to raise additional financial resources for water programs.

\section{Include communities, especially women and farmers}

People used water, and people live in communities and more and more in urban areas. Marcia Brewster noted that women are the key to awareness and community action. Interestingly, Deputy Assistant Secretary for Agriculture, Dr Ann Bartuska said there had been a significant increase in the number of women in the United States, according to the recent studies, it has shown that women play a central role in the supply, management and preservation of water, one of the four principles of water management accepted at the international level. This principle is particularly important for developing countries, especially Nigeria, where millions of women do not have access to water for their essential needs. Furthermore, since farmers use $70 \%$ of water in the world and given that $13 \%$ of farmers produce $80 \%$ ' food supply, they must be given top priority.

\section{Measure and put appropriate price on water}

Leaders say that "what is measured is managed" and that water is not exceptional. The data crystallize and validate, challenge action and help us see trends and progress. Thus far, there is need to address obsolete and aging water infrastructure since little is charge for water and yet it costs so much to maintain. Since the necessary infrastructure was lacking and obsolete in most developing countries and an upward trend in water prices without improvement in service quality will resulted in strong consumer dissatisfaction. Therefore, restoring the link between prices and quality of water services. However, water pricing and related rights go on while rising prices will reduce waste and pollution. 


\section{Integrate water into trade policy and environment}

Trade is an important driver to economic growth, but also with potential significant effects on the environment, particularly in this era of globalisation which has in part reduced barriers to International trade and investment flows. Nigeria is driven by economic and political forces rather than by water scarcity. It is necessary to integrate water and development issues, including their effects on the environment, in trade and development policies. We need to integrate water management, conservation and sanitation into commercial policy. ${ }^{33}$

\section{Protecting the poor}

The poorest among us use "every drop of water available". Thus, when they have a little less, the impact is huge. Without political influence, everyone must monitor themselves, including those most vulnerable to shortages and disasters related to climate change, with the weakest infrastructure and the least resilience.

\section{Citizens' action and education}

Knowledge is one of the most strategic tools in reducing health problems from water crisis in any environment. It allows us to understand what is harmful, why and possibly how to avoid such harm. In the end, changing the face of this crisis goes through the education / advocacy of citizens to motivate new behaviors. In order to cope with the era of shortage of water, it will need to revisit all forms of consumption, from the individual use to the supply chain of large companies. Some regions are already facing the water crisis such as India, Australia and the southwest of the United States. The most critical task is to ensure that the problem is much better understood at the global level. ${ }^{33}$

\section{Inventing new water conservation technologies}

In the areas where the aquifers and wetlands are disappearing and where the rainwater is acidic and becomes more and more unpredictable, there is need for more creative and innovative ideas to solve water crisis. But while we are trying to cope with the shortage of fresh water and to develop conservation technologies, energy consumption is an important factor to take into account. Another feasible strategy is to use water resources more efficiently. This is particularly important, since a number of studies show that local overexploitation is in most cases a far more significant cause of water scarcity than climate change. UNESCO's World Water Development Reports, for example, identify many possibilities for using water more efficiently, while access to technological innovation in poorer countries continues to play an important role.

\section{Recycle wastewater}

Recycle more water will help us reduce water waste and increase reserves. In March, World Water Day speakers recommended a new state of mind for wastewater treatment. Some countries, such as Singapore, try to recycle to reduce water imports and become more self-sufficient. The rich republic of East Asia plays a leading role in the development of a leading technology that cleanses wastewater for other purposes, including beverages.

\section{Encouraging agricultural irrigation practices and im- provement}

Approximately $70 \%$ of freshwater is used for agriculture. Improving irrigation can help bridge the gap between supply and demand. In some cases, abusive irrigation practices for an earlier period have weakened the ability of farmers to provide food and fiber in a growing population. Examples include the Murray-Darling basin in Australia, the Aral Sea in Central Asia and the Southwest. Although new technologies have become an attractive solution and success can be achieved by improving what is already in place. ${ }^{33}$

\section{Research promotion [including developing energy efficient desalination plants]}

Several lines of ecological and environmental health research are needed to provide data-based support for public health actions on water crisis. These include empirical research on the association between water crisis and health, ability to forecast health impacts and vulnerabilities, development and testing of strategies to reduce risk etc. To be successful, an overarching research program needs to be integrated, focused, interdisciplinary, supported and sustainable, yet flexible enough to adjust to new information and broad enough to cover the very diverse components of the environmental health research. Furthermore, research efforts must be multinational, multiagency and multidisciplinary bringing together the strengths of all partners. Research promotion that will allow us to use solar energy to desalinate water for increasing supplies and to purify the water we use. Similarly, to date, desalination is an energy-intensive solution to address water scarcity. In general, the Middle East has taken advantage of its large energy reserves to build desalination plants. However, Saudi Arabia may favor a new type of desalination by recently announcing the use of solar power plants. There is therefore need to emphasis innovative technological experimentation in the area of agriculture. ${ }^{33}$

\section{Community based partnerships and governance}

Community councils promote the effects of the voiceless being more influential. Moreover, partnership between communities and underrepresented groups should be strengthened. The most effective government guarantees in many community-based activists can effectively lead to exchange of policies at the country of origin. ${ }^{33}$ Also, building the capacity of the local authorities to oversee the water interventions and improving the monitoring and benchmarking of the water providers by the water resources ministry to strengthening institutional capacity of the Water Regulatory Authority.

\section{Preserving biodiversity/wetlands}

Preserving biodiversity by avoiding disruption of aquatic systems and their bordering terrestrial system as a key factor in maintaining water suppliers and water quality. Thus-far, all-inclusive management applies to a practical, common-sense approach to overseeing natural resources that considers economic, cultural, and ecological goals. Essentially, all of its parts are larger than sum, and each one has a bearing on the effects of others. The best examples of holistic management are communities that operate sewage treatment plants while pursuing partnerships with clean energy producers to use wastewater to fertilize algae and other biofuel crops. The crops, in turn, soak up nutrients and purify wastewater, significantly reducing pumping and treatment costs.

\section{Improve distribution infrastructure and catchment}

Health and economy devastation results from poor state of water infrastructure. It eliminates resources, adds money, reduces the quality of life, and allows the disease that is dangerous to spread among vulnerable people, especially children. The problem is not limited to only developing countries alone. Such problems include regular pipes burst, regular overflow and malfunction etc. Similarly, Watercourses are important for areas with no reliable source. 


\section{Address pollution}

Water pollution is a great disaster to many countries in the tropics which underpins every aspect of human and environmental existence. Water impediment affects human health, economic growth, and the environment. It highlights the potential competition between water users for water-free applications. Pollutants can be both human induced (e.g, microbiological contamination, eutrophication and excess of nutrients, acidification, metal pollutants, poisonous toxicity, saltwater contamination, thermal pollution, and total inhibition) and natural (e.g, salinization, arsenic and fluoride). However, the pollution of water occasioned by oil spillages and oil exploration activities is the most important and damaging in the affected region (Niger Delta). ${ }^{1-7,16,18}$, Massive water pollution reduces production of farming and economic growth. ${ }^{34}$ Therefore, measuring and maintaining water quality is essential to health of fauna and flora including human health. This issue rears its head in many forms and can be solve in different forms. While it's important to build an international collaboration to securing drinking water quality. ${ }^{5}$ The severe water challenges facing the world today require an unprecedented global response. Nothing or little is done by the governments at various level to make provision of clean and accessible water to the citizens.

\section{Equitable access to common resources}

Despite Nigeria enormous natural wealth, it remains a poor country. About $70 \%$ of Nigerians are estimated to be living the poverty level of $\$ 2 /$ day. Poor households rely disproportionately on water resources and the environment for their livelihood and income. In the process of water exploration, the natural environment is polluted, and livelihoods extinguished to the extent that poverty becomes more pronounced. Since, one of the United Nations Development Goals (SDGs) is to ensure access to drinking water. While the steps to reach this goal are discussed, the theory that water is a fundamental right comes into play. Countries like Chile are trying to reform water rights. ${ }^{33}$

\section{Systemic thinking and innovation}

Access to water in a society where water is rare will become a bigger priority in business decisions. Communities are likely to seek publicprivate partnerships that exploit business innovation capabilities. For example, city that operates wastewater plants will probably pursue its partnership with clean energy producers to fertilize algae and other biofuels with wastewater. Remarkably, many individual Nations as well as development partners are rethinking water policy and putting greater emphasis on development principles that reflect environment, social and cultural values. Among the major principles that appear to be common to all these new approaches are:

i. Basic human needs for drinking water and sanitation services must be met.

ii. Basic ecosystem needs for water must be met

iii. The use of non-structural alternatives to meet demands must receive higher priority

iv. Economic principles must be applied more frequently and reliably to water use and management

v. New supply systems, if needed, must be flexible and maximally efficient

vi. Development partners i.e. NGOs, individuals, independent research organisations and other affected stakeholders must all be involved in water management decision.

\section{Technology transfer on water-related projects}

Climate change and scarcity of water have the most dramatic consequences in developing regions, particularly in Sub-Saharan Africa. A suggested solution is to transfer water conservation technologies in these dry areas. This is delicate because economies are low and there are gaps in skills that often require governmental authorities and businesses to impose these changes on local citizens.

\section{Mitigation of climate change}

Climate change and water shortages go hand in hand to cause some of the greatest contemporary human race challenges. These issues have a mutual relationship, identified by the Intergovernmental Panel on Climate Change (IPCC), in which "water management policies and measures can influence greenhouse gas emissions (GHG)". The use of these mitigation tactics needs to be taken into account in the production of alternative bio-energy crops to hydroelectric and solar plants. $^{33,35}$

\section{Population growth control}

Controlling human population growth is fundamental to using water resources more sustainably and efficiently while maintaining water quality. Due to the global explosion of population, some parts of the world may experience a gap between water supply and demand for up to $65 \%$ by 2030 . At present, more than one billion of people do not have access to drinking water and about 70 percent of freshwater is used for agriculture, the critical role of water in food production must be considered as a climate change and resource conditions. ${ }^{33}$

\section{Creation of a databank for baseline information}

There is paucity of information to help in the planning and management of water supply. For instance, any information given for per capita consumption of water will be misleading as water supplied to all parts are not the same? A lot of information is needed for effective decision-making during planning and management of water supply. One basic step to effective planning and management of water supply and its availability is to ensure that accurate information is available to the planners and managers of water supply.

\section{Needs assessment and prioritization of actions}

Since the water sources including quantity and quality available to each community are different as well as the population of the residents requiring water, there is therefore the need to ascertain the actual need of the people from one community to another. This will generate needed baseline data for effective water delivery planning and management. To ensure water availability and need assessment should be done.

\section{Effective institutional arrangement is necessary}

A clearly defined institutional framework must be put in place. This will check overlap of responsibilities and therefore ensure that there is no role conflict that will result in neglect or dereliction. Effective institutional framework for sustainable water supply and management will imply that the institution is vested with this responsibility and no other institution/agency is expected to perform the same responsibility to avoid role-conflict. Moreover, in view of the enormity of the responsibility, for sustainable water availability, supply and management. The state government agency should be strengthened in terms of manpower and financial resources to be able to perform creditably well. Regular training and capacity building of personnel to be able to cope with the responsibilities will also 
constitute an effective institutional strengthening for sustainable water availability, supply and management.

\section{Conclusion and recommendation}

In a world where demands for safely managed water are continuously growing, and where limited water resources are increasingly stressed by pollution, over-abstraction and climate change, neglecting the opportunities arising from improved water management is nothing less than unthinkable. Tackling water crisis and its pollution requires an effective and efficient set of policies, technologies, and scientific advances on very different scales. Demand for global water is generally projected to increase by 30 to 50 percent by 2050 and rising global population, income, and urbanization are causing strong growth in food and water demand and intensified competition for water. More than one-third of the world population approximately 2.4billion people already live in water scarce counties, or river basins with annual water withdrawals greater than 40 percent of total renewable water. Hence, water is a vital resource that is becoming increasingly scarce and threatens to undermine the progress that has been made on global food and nutrition security. With the potential for severe economic, political, and humanitarian consequences across emerging countries, water scarcity is a critical global issue that demands immediate action to improve water productivity and management. The challenges are daunting and will only become more difficult if not addressed.

In spite of the challenges faced by the country in respect to water scarcity, few States have been able to get closer to water access to its citizen. Due to its link with poverty, the scarcity of water is a decisive test for achieving the global ambition of "sustainable development goals". A vigorous and co-ordinated action is therefore needed by all the affected States, donors, the private sector, the academic world and the research organizations to strengthen interventions and to prevent the insupportable loss of productive time and life. States and development partners need to partner together to embrace the current global momentum around sustainable water access to all and raise additional financial resources for water programmes. To achieve the objectives of the specific sustainable development goals, States and development partners facing the scarcity of water must take concerted measures to reduce the number of deaths associated with the water crisis. To reach all States and all communities affected by interventions in the field of water, a strong political commitment and significant expansion of international and national financial resources are required. Hence, there is an urgent need for increased awareness among Nigerian leaders so that adequate strategies can be made for development under conditions of severe water scarcity. The time to act on fundamental reform of water policies is now. Successful, sustainable water management is imperative to achieve the goals of a rapidly growing, urbanizing world. Several strategies can be used to address the challenges posed by increasing water scarcity. These include:

i. Improving overall water resource governance through institutions that are transparent, accountable, efficient, responsive, sustainable, and geographically contextualized. Also, allocating water more efficiently through water rights, regulations and quotas, water pricing, water trading, and subsidy reform etc.

ii. Democratization of the Nigerian State and its constituencies should be a priority. In the current situation, Nigeria is deeply concerned; and considering its actions and policies, the state has become a major obstacle to democracy governing natural resources, including water resources. ${ }^{22}$ In the democratic state of the country, they are aimed at pushing the politics of a narrow political party as a means of generating wealth, meeting with the commonwealth of all, and improving the quality of society. In fact, the purpose of the policy is to improve the lives of people and improve their physical condition, which can be achieved through redistributing rights on human resources but denying the state its power has to rely on resources. ${ }^{22}$

iii. Democratic democracy must be governed. The aim of democratizing and managing human resources is to provide citizens with the aim of their right to own, manage and manage raw materials currently being usurped by state. It affects redistribution of power over the state's national resources to the people. ${ }^{22}$ In this way, inequality and social injustice, as well as other confusions and philosophies, that have characterized the path the state for the production of raw material, benefit from a few, while most Nigerians fall into nourishing poverty when they were defeated. The use of the strategy for natural resources leadership in governance of democracy is that of stress, oppression, killings, torture and corruption that characterize the state response to the agitation in the oilproducing communities, the nation will gradually eliminate it. However, the huge presence of armed forces or militias in the Niger Delta area is increasing rather than reducing residence, threatening security for the oil companies and members of the members of the local communities.22

iv. Managing water resources management should be part of a community-based policy plan. Unlike the management of water resources, which does not necessarily address issues related to rights, ownership, fairness, accountability, etc., direct space management will solve these problems and other related issues. As a source of life, this means that the place of power and water resources authority does not really agree with clarifying the rules, but with a struggle between the state, the oil companies, national groups and community groups and society. ${ }^{22,27}$

v. Strengthen the environment for cooperation and communication between water development and other stakeholders; leverage on expert influence to improve water resources governance and sustainability including easing the challenges that could hinder greater private sector investment to expand sustainable water development.

vi. Community-based calculation on resource upgrade of equipment. As part of the democratic process continues to develop strategic issues, development and power, including infrastructure, will be for many people, community groups, and states, to decide recommended the size of the water projects, among other social services, allocated and they want; rather than in the situation, they are in the state of quality water efficiency. People tends to own such infrastructure, since it is considered as their own. ${ }^{22}$

vii. Need for a forum for the representatives of state government and stakeholders of water resources in the state demanding that both humanitarian and development partners work together from the beginning of a system that will be resilient. At such gathering, there will be a look at water resources, success achieved, constraints identified and resolved. ${ }^{22}$ This will provide a strong reason for the government, development partners (NGOs), community groups, the capital and the issuer 
of agencies in creating a government and private partnership on water resources and providing water access services, sanitation and cleaning facilities. ${ }^{22}$

viii. Land policy favorable to the poor. Its fundamental objective should be the restoration of the title of ownership on the land and its content as well as the recognition of the exclusive character of common resources. As a result, women access to the same rights and resources as men is critical to improving productivity along with food and nutritional security. In fact, a population-based land policy will help reverse the appropriation by the state of the rights of the people, allowing them to operate and control their land, which would involve the people in the development process. ${ }^{22}$ A landmark policy favor to the poor will require the Nigerian state to regain its preferential dependence on self-sufficiency, in the way the land is governed in the country. Failure to treat water as a strategic, valuable and limited resources will accelerate water crisis and will hinder the achievement of sustainable water for all particularly in a rapidly growing and urbanizing society. Without skeptism, the enactment of the above requirements will lead to the safety of water and the promotion of rural development in Nigeria. Moreover, it would be false to think that the government of the state would not resist them. ${ }^{22} \mathrm{I}$ am not blaming the government. But to create awareness on accessibility to clean water towards a water wise world and to the progression of water management globally. Moreover, we are not only helping our generations but also the generation yet unborn. ${ }^{36-43}$

\section{Acknowledgments}

None.

\section{Conflicts of interest}

The authors declare that there are no conflicts of interest.

\section{References}

1. Raimi Morufu Olalekan, Oluwaseun Emmanuel ODIPE, Nimisingha Deinkuro Sanchez, et al. Assessment of Environmental Sanitation, Food Safety Knowledge, Handling Practice among Food Handlers of Bukateria Complexes in Iju Town, Akure North of Ondo-State, Nigeria Acta Scientific Nutritional Health. 2019;3(6):186-200.

2. Raimi MO, Abdulraheem AF, Major Iteimowei Odipe OE, et al. The Sources of Water Supply, Sanitation Facilities and Hygiene Practices in an Island Community: Amassoma, Bayelsa State, Nigeria. Public Health Open Access. 2019;3(1):000134.

3. World Bank. World Development Report. 2006.

4. Siddiqui NA, Akbar Z. Natural Resources and Environmenta Management Systems. Khanna Publishers. Nai Sarak, Delhi India. 2008

5. Morufu Raimi, Clinton Ezekwe. Assessment of Trace Elements in Surface and Ground Water Quality. Lambert Academic Publishing. 2017.

6. Raimi Morufu Olalekan, Sabinus CE. An Assessment of Trace Elements in Surface and Ground Water Quality in the Ebocha-Obrikom Oil and Gas Producing Area of Rivers State, Nigeria. International Journal for Scientific and Engineering Research (Ijser). 2017;8(7).

7. Olalekan RM, Omidiji AO, Nimisngha D, et al. Health Risk Assessment on Heavy Metals Ingestion through Groundwater Drinking Pathway for Residents in an Oil and Gas Producing Area of Rivers State, Nigeria. Open Journal of Yangtze Gas and Oil. 2018;3:191-206.

8. Sodhi GS. Fundamental Concepts of Environmental Chemistry. Second edition, Narosa Publishing House ltd. 2005.
9. Ringler C. Role of Water Security for Agricultural and Economic Development - Concepts and Global Scenarios. In Handbook on Water Security, ed. Claudia Pahl-Wostl, Anik Bhaduri, and Joyeeta Gupta (Cheltenham, UK: Edward Elgar Publishing Limited, n.d.). 2010;183200 .

10. Wada Y, Van Beek LPH, Bierkens MFP. Modelling Global Water Stress of the Recent Past: On the Relative Importance of Trends in Water Demand and Climate Variability. Hydrology and Earth System Sciences. 2011;15(12):3785-808

11. Khitoliya RK. Environmental Pollution, Management and Control for Sustainable Development. S Chand and company ltd, New Delhi. 2004.

12. Yamaguchi Ayami, Sae Tanaka1, Shiho Yamaguchi, et al. Two Novel Heat-Soluble Protein Families Abundantly Expressed in an Anhydrobiotic Tardigrade. PLoS ONE. 2012;7(8):e44209.

13. www.course.lumenlearning.com

14. Emiliano Brini, Christopher J Fennell, Marivi Fernandez-Serra, et al How Water's Properties Are Encoded in Its Molecular Structure and Energies Chemical. Reviews. 2017;117:12385-12414.

15. Garg SK, Rannjini G. Environmental Studies and Green Technologies. Khanna Publishers, Delhi. 2008.

16. Henry O Sawyerr, Odipe E Oluwaseun1, Olawale S Asabi, et al. Bacteriological Assessment of Selected Hand Dug Wells in Students' Residential Area: A Case Study of Osun State College of Health Technology, Ilesa, Nigeria. Global Scientific Journal. 2019;7(1):1-6.

17. World Health Organisation (WHO). International Meeting on the Management of Water Quality in Rural and Remote Communities. World Health Organization, Geneva. 2006.

18. Raimi MO, Pigha Tarilayun K, Ochayi EO. Water-Related Problems and Health Conditions in the Oil Producing Communities in Central Senatorial District of Bayelsa State. Imperial Journal of Interdisciplinary Research (IJIR). 2017;3(6).

19. Olalekan RM, Omidiji AO, Williams EA, et al. The roles of all tiers of government and development partners in environmental conservation of natural resource: a case study in Nigeria. MOJ Ecology \& Environmental Sciences. 2019;4(3):114-121.

20. Augustine OE, Zachariyau A, Olarunda JO, et al. The Sanitarian and His Work. A Practical Guide to Environmental Health Practice first edition, Juaainchrist Printers. 2009

21. Olalekan RM, Vivien OT, Adedoyin OO, et al. The sources of water supply, sanitation facilities and hygiene practices in oil producing communities in central senatorial district of Bayelsa state, Nigeria. MOJ Public Health. 2018;7(6):337-345

22. Omoweh DA. The Paradox of Water Crisis and Rural Poverty in the Niger Delta of Nigeria: The Case of Bayelsa State. In: Ayeb H and Ruf T, Editors. Eaux, pauvreté et crises sociales. IRD Éditions. 2009.

23. Daniel A Omoweh. Shell Petroleum Development Company, the State and Underdevelopment of Nigeria's Niger Delta: A Study in Environmental Degradation. Trenton. 2005. p. 300

24. Daniel A Omoweh. Resources, Governance and Democratization in Africa. The International Journal of African Studies. 2005;5(1)

25. Garret Hardin. Tragedy of the Commons. Science. 1968;162(3859):1243-1248.

26. Bromley, Cernia. The management of common property/Natura resources: Some Conceptual and Operational Fallacies. World Bank Discussion paper, no. 57. 1989;1-84.

27. Daniel A Omoweh, Dirk van de Boom. Blocked Democracy in Africa: Experiment with Democratization in Nigeria, 1999-2003, Abuja: KAF. 2005. 
28. Raimi Morufu Olalekan, Tonye V Odubo, Omidiji Adedoyin O, et al. Environmental Health and Climate Change in Nigeria. World Congress on Global Warming. Valencia, Spain. 2018.

29. One World-UK. One World Water and Sanitation Guide. 2008.

30. UNESCO. The United Nations World Report 2, Water: A Shared Responsibility, UNESCO, Paris. 2006.

31. Butterworth J. Multiple uses of domestic water systems. 2006.

32. Jegede GB. Handbook on Pollution Control and Environmental Health Practice for Developing Countries. Designed and printed at Steadfast Computer and Graphix, Abuja. 2010.

33. www.circleofblue.org/2010.

34. Mark W Rosegrant, Claudia Ringler, Tingju Zhu. Water for Agriculture: Maintaining Food Security Under Growing Scarcity. Annual Review of Environment and Resources. 2009;34(2009):205-222.

35. Raimi Morufu Olalekan, Omidiji Adedoyin O, Abdulraheem Aishat Funmilayo, et al. A Survey of Hand Washing Behavior and Awareness among Health Care Workers in Health Care Facilities in Kubwa District of Bwari Area Council, F.C.T. Abuja, Nigeria. Annals of Ecology and Environmental Science. 2018;2(2):1-18.
36. Carla WM. Environmental Geology. Seventh edition, McGraw Hill Higher Education. 2006.

37. Daniel A Omoweh. Political Economy of the Operation of Shell Petroleum Development Company in the Oloibiri Area of Nigeria. Report of Study submitted to the Bread for the World, Stuggart, Germany. 1998.

38. Iloeje J. Geography of Nigeria, Lagos. 1974.

39. National Population Commission Abuja, Nigeria. 2006 Housing population Census: Population on distribution by age and sex: State and Local Government Area, Priority able. 2010;4:54-58.

40. Okot-Ogendo. The Tragic of the Commons: A century of Expropriation, Suppression and Subversion. Proceeding of the African Public Interest law and Community-Based Property Rights Workshop, Arusha, Tanzania. 2000;1-4.

41. Rao PV. Textbook of Environmental Engineering, Eastern Economy Edition. PHI Learning Private Limited, New Delhi. 2010.

42. https://www.huffpost.com/entry/solutions-to-the-global-w_b_5348386 Access December 2017.

43. www.news.bbc.co.uk/2/hi/africa 